\title{
Launching a Revolution, based on Islamic Foundations
}

\author{
Asad Zaman \\ Former Vice Chancellor \\ Pakistan Institute of Development Economics, Islamabad
}

\begin{abstract}
Conventional economics is deeply and fundamentally flawed, beyond the possibility of reform and repair. Its failings in the real world became obvious to all following the global financial crisis. The root of the problem is the theory of human behavior represented by "homo economicus". The idea that short-sighted greed is "rational" is sheer folly. The theory is maintained in face of overwhelming empirical evidence to the contrary only because it serves the ideological interests of the rich and powerful capitalist classes. The philosophy of wealth maximization has led to the destruction of families, societies, economies, environment, fauna, and flora, as all are ruthlessly exploited for the creation and maximization of profits. Islamic teachings created a revolution in world history by promoting a society based on cooperation, generosity, and social responsibility. These ideas, completely missing from modern economics, have the same revolutionary potential today. The challenge for the Muslims today is to demonstrate this potential by translating these ideas into reality.
\end{abstract}

Keywords: Economics education, Pluralism, Islamic economics, Power/Knowledge.

JEL Classification: A2, B2, Y8

KAUJIE Classification: G0, G1, H1, H22, H6 


\section{Relevance of Economics to Real World Problems}

I would like to thank the editors of JKAU:IE for opening a dialogue on this burning topic, very much the need of the moment. Jack Reardon has presented an excellent summary of key issues in the lead paper (Reardon, 2019), with which I am very much in agreement. Building on the foundations provided by him, I will add further details, especially from the point of view of rebuilding Islamic economics on new foundations.

What is the relevance of economics to real world problems? Let me start with the concluding paragraph of Jack Reardon's answer to this question:

I blame neoclassical economics and its economics education for the inability to see our rapidly changing economy. For its inability to offer $21^{\text {st }}$ century solutions for our $21^{\text {st }}$ century problems. For its inability to produce big thinkers. For the failure to reconceptualize capitalism so that it produces wealth while minimizing poverty and inequality, and for its failure to devise effective solutions for climate change. I have made it my life's work to change how we educate our economists. To paraphrase Charles Snow, "There is no excuse for letting another generation be as vastly ignorant”. (Reardon, 2019, p. 63)

There are two key take-aways here.

(a) 'Whether or not economics is relevant' is a misleading question. In fact, economics is actually the main problem that requires a solution. The way economics theory is taught blinds us to the central problems which need solution today.

(b) The solution lies in changing the way we educate economists, and by extension the general public. Just like Jack Reardon, I have also devoted my life to developing a radically different form of economics, built on Islamic foundations.

I would add to this point by asking the question of why economics is an obstacle to understanding our contemporary problems, rather than being helpful in finding solutions. First, I will state three propositions, each of which requires detailed study, which I have provided elsewhere. For present purposes, I will not provide arguments, but only the assertions:
1. Economic theories are dramatically in conflict with observed realities. Behavioral economics shows how neoclassical utility theory completely fails to match actual observed human behavior (see Zaman \& Karacuka, 2012 for a survey). Hill and Myatt's Economics Anti-Textbook (2010), lists all the central propositions of microeconomic textbooks and shows how they are wrong. The global financial crisis made it clear to all that current macroeconomics completely failed to see the crisis, and also failed to provide policies to prevent the Great Recession which followed.

2. Even though flaws in economic theories are easy to see and prove, economists are stubbornly resistant to change. Paul Romer in The Trouble with Macro (2016), documents how economists refuse to change theories which are violently in conflict with facts. When the Keynesian revolution created theories and policies which stated that free market generates unemployment, and government policies must be used to create full employment, the Monetarist counter-revolution put pre-Keynesian theories back in place. According to current theories, in the latest textbooks of labor economics, the massive unemployment in the Great Depression and the Great Recession was because laborers preferred enjoying leisure because the wages being offered were not sufficient to compensate them for the disutility of labor. The absurdity of this theory can be established by many different methods.

3. Why is there such strong resistance to change, and why do economists cling to absurd theories in the face of very strong empirical evidence to the contrary? This can only be explained by the Power/Knowledge thesis of Michel Foucault. Theories dominate not because they are true, but because they are aligned with the interests of the powerful. For example, Keynesian theories advocated the interests of the unemployed laborers. However, providing jobs works against the interests of the capitalists, who benefit from the helplessness of laborers. That is why Monetarists prevailed against Keynesians. 


\section{Is There A Need for Reform of Economics?}

As discussed in the answer to the previous question, "reform" is the wrong word to use in the context of power/knowledge. Economic theory is an instrument of power, and to try to "reform" it is to engage in a power struggle on behalf of the billions living in poverty today. The traditional economic diagnosis of "scarcity" says that to eliminate poverty, we must get more goods, in order to be able to provide for the poor. The fact of the matter is that the goods currently available are hundreds of times more than what is required to satisfy the basic needs of everyone on the planet. So, the central problem of economics is one of "Re-Distribution". How can we get the excess wealth of the rich - which they will never use for their own consumption - into the hands of the poor? Of course, this way of looking at the matter is exceedingly harmful to the interests of the rich and powerful, and hence, economic theory avoids discussions on inequality and re-distribution to the extent possible. For instance, a Nobel Laureate advocate of the free market, Robert Lucas, said that "Of the tendencies that are harmful to sound economics, the most seductive, and in my opinion the most poisonous, is to focus on questions of distribution" (Lucas, 2004, last para).

So, when we talk about reform, we really need to discuss strategy - how can we prevail in a political battle against the rich and the powerful, who control the media, and are major donors to universities? The power/knowledge thesis works in both directions. Just as possession of power allows control of the flow of knowledge, so access to knowledge creates the power to bring about meaningful changes. The knowledge provided by Allah Almighty - who gave man knowledge that he did not have - catapulted ignorant and backwards Arabs to world leadership. Today, Islam provides with this same powerful knowledge, which has the potential to launch a revolution in all domains of social sciences, including economics.

The power/knowledge thesis is an outgrowth of Marxist theory, which has complete clarity on the issue that to reform economic theory is to call for a revolution on behalf of the poor. The required reforms will take away surplus wealth from the rich, who have obtained this by exploiting labor, and other planetary resources. This excess will be given to the poor laboring class, as well as all who are in need of it. The strategy of the Marxists is to call for a class war of the poor against the rich: 'Workers of the world unite; you have nothing to lose but your chains' (Marx \& Engels, 1848/1908). History bears witness to thousands of revolutions of the poor against the rich, with the vast majority being unsuccessful.

Islam offers a radically different approach and strategy for the same problem. It calls for a realization of the brotherhood of all human beings. It asks us to struggle to spread the good - that is, the values of cooperation and generosity. It asks those who have surplus to give to those who are in need, for the love of Allah. It also enforces a compulsory tax of $2.5 \%$ on the wealth of the rich, for the explicit purpose of aiding the poor. It asks the entire society to insist on 'the feeding of the poor' - that is, it creates awareness of our collective social responsibility for taking care of the bottom segment of the population. All of these measures are outside the scope of conventional economics, but central to Islam.

\section{Is Pluralism the Answer?}

Control of access to information is one of the key strategies for the rich and powerful. In particular, economic theory is so amazingly wrong, and so amazingly easy to refute, that the top $1 \%$ cannot afford pluralism. Once a sensible alternative is displayed, people will easily see the falsity of conventional theory. That is why the present methodology of teaching economics is a form of brainwashing, rather than education. The teacher claims to have exclusive possession of truth, and insists that the student learn this truth. There is no room for debate or discussion. This makes pluralism an effective counter-strategy. It is much easier to ask that alternatives should be presented, and students should be allowed to discuss and debate among different possibilities. This stance seems reasonable and hard to resist. Even though mainstream orthodoxy continues to successfully resist such calls for pluralism, this does weaken their case in front of a neutral and unbiased audience.

From the beginning, Islam has encouraged people to think, argue, reason, and to choose the pathway to Allah. As Allah Almighty states in the Holy Qur'ān 
"And if we had willed, We could have given every soul its guidance" (32:13). But, instead of forcing guidance upon everyone, $\mathrm{He}$ has left us free to choose: "whosoever wills, let him take a Path to his Lord (Allah)" (76:29). The Holy Qur'ān is full of appeals to reason and to our emotions, to make us recognize the truth. It also explains that there is no compulsion in religion, and all will be judged fairly. The Holy Qur'ān states:

Surely those who believe, and those who are Jews, and the Christians, and the Sabeans, whoever believes in Allah and the Last day and does good, they shall have their reward from their Lord, and there is no fear for them, nor shall they grieve. (2:62).

Once we penetrate the facade of objectivity, it is easily seen that modern economic theory is actually a religion. This point is made at length by Nelson (2014) in "Economics as Religion" (see also, the brief review by Gauthier, 2017). The idea that all rational human beings should maximize the lifetime pleasure they derive from consumption of goods and services is exactly what the Holy Qur'ān calls the religion of worship of the nafs (self). About such people, the Holy Qur'ān states:

Have you seen he who has taken as his god his [own] desire, and Allah has sent him astray due to knowledge and has set a seal upon his hearing and his heart and put over his vision a veil? (45:23)

Worship of our own desires blinds us to the realities of human experience, which may account for why economists make "assumptions profoundly at odds with what we know about consumers and firms" (Blanchard, 2016, p. 1; for additional similar quotes and sources, see Zaman, 2018).

From an Islamic perspective, pluralism serves rather different functions. One of them is to allow for free choice from among alternatives. Since there is no compulsion in religion, we must choose freely between the religion of economics (worship of desires) and the religion of Islam (worship of Allah). The Holy Qur'ân asks us to choose the love of Allah and His messenger and striving in His cause, over the love of wealth, profits, housing, relatives, and material comforts (9:24). Allah Almighty could have compelled obedience upon all of us. Instead, He has shown us the two highways (of good and evil), and has left us free to choose between them. "Whosoever wants to, let him choose a pathway to his Lord (Allah)" (Qur'ān, 76:29). This means that we must examine and evaluate potential alternative life choices, and freely choose Islam as our path.

A second important aspect of pluralism is allowing for the possibility of multiple truths. This is at the heart of the deep tolerance which is unique to Islamic traditions. This tolerant attitude comes from the earliest times in Islam, and has been elaborated by many writers (see for example, Shah WaliuAllah, 1750/ 1995, and Zakariyya, 1938). More accessible to English speaking audience are the discussions by Menocal (2002) and Walbridge (2002) of the tradition of tolerance and its significance in Islamic history. As an illustration, there are four different established schools of religious thought, which have sharp disagreements with each other on many important theological questions. In contrast, Western philosophy is committed to a binary theory of truth - statements are either true or false - which precludes pluralism. It leads to the attitude of 'either you are with us or against us', as well as the idea that anyone who disagrees with me is wrong. Zaman (2016a) provides a deeper discussion of the philosophical mistakes which led Western philosophers to these erroneous theories about the nature of truth and logic .

\section{How Genuine Have Been the Calls for Reform?}

Consistent with the power/knowledge framework that underpins the construction of modern economic theory, the calls for reform from the bottom $90 \%$ have indeed been very genuine. Billions of people on the planet lack access to basic necessities, and have no opportunities for economic advancement. After the Great Depression, which was caused by very similar forces, there was a genuine reform of the economic theory and policy. Keynesian economics acknowledges the failure of the free market to provide full employment and asks for government intervention to create jobs for all. The New Deal of Roosevelt created policies to regulate finance and provide jobs. These actions were all contrary to the dominant laissez-faire and free market principles, which provide maximum power to the rich and wealthy. However, the situation has been very different after the global financial crisis. The financial lobbies are very much 
in control of the regulatory bodies and Congress. Motions for regulation have all been defeated. After the crisis, according to official FBI reports as well as many other sources, financial institutions defrauded the public of millions, creating the highest level of homelessness and hunger seen in the USA in the post war era. Nonetheless, instead of prosecution and punishment, the financial sector was rewarded with 29 trillion dollars in bailouts, while the defaulting mortgagors were thrown to the wolves. Just as there has been no change in regulations, so there has been no change in economic theories. The complete failure of economists to anticipate the crisis, and even more importantly, to suggest remedies which could have prevented the Great Recession which followed, was widely observed. The Queen of England went to the London School of Economics to ask, "why no one saw it coming' (Bezemer, 2009). The US Congress appointed a commission to study the failure of economic theory in the global financial crisis.

Despite this widespread public awareness of failure, there has been no change within the economics profession, which continues to defend the same old ideas. The same DSGE models which have no possibility of crises in them, because rational expectations preclude them, continue to be used at central banks all over the world. The same GARCH models for estimating volatility, which failed completely in the global financial crises, remain in use. The same macro theories which cannot conceive of disequilibrium and crises, continue to guide the theorizing of economists. Economists who acknowledge the failure, continue to advocate making minor tweaks to fix problems, and continue to assert the fundamental soundness of mainstream economic theories. Many authors have remarked on the strong resistance of the profession as a whole to any significant change. There are many reasons for this failure to make the needed reforms. One of these is that the faculty which has been taught deeply defective theories is firmly entrenched in the academic institutional structures. They produce thousands of PhD's every year, who are trained in the obsolete techniques. Radical changes pose an immense threat to power, prestige, ranks, salaries, and jobs for the establishment. So, calls for radical change are strongly resisted, while minor tweaks are happily accepted.
To summarize, outside the profession, the calls for change have been very genuine. Within the profession, there is only a token response to the call for reform, to create an appearance of change while carrying on business as usual. Morgan (2015) shows how the profession views the problems created by the global financial crisis as merely those of bad publicity, which requires better communication strategies, rather than substantive change. Steve Keen (2016) also discusses the "slowly changing resistance of economists to change".

\section{How Useful Have Been the Reforms?}

As already discussed in the previous section, the interests of mainstream orthodoxy lie in strongly resisting reforms, while paying lip-service to the need for reform, and creating an appearance of change. This means that while useful proposals for genuine reform are available, none of them have made into the syllabi of the mainstream economic academic programs. Outside the arena of orthodoxy, there is a vast range of reformers, and heterodox ideas, which are gaining strength due to the chaos created by the global financial crisis. Madi and Reardon (2014) provide a good survey of critical innovations which have been suggested for reform. In particular, Zaman (2014b) provides a discussion of why most calls for reform do not go far enough, and also why the task of reformers is substantially more difficult than commonly envisaged. To create genuinely useful reforms, we need a deeper understanding of how the present state of affairs came about. In particular, how did economic theory lose its ethical and moral content, and how did it get detached from its historical context? This is discussed briefly below.

The modern capitalist system emerged via the "Great Transformation" which was a revolution in ways of thinking, acting, and organizing the political, economic, and social structures of society. Zaman (2010), provides a good discussion of the great transformation which led to the emergence of a market society. Unfortunately, at the heart of the capitalist system is the drive to accumulate wealth by exploiting everything over which power can be exercised, including humans, animals, the bio-system, and the eco-system. This is destroying our lives, families, societies, flora, fauna, and the planet, as we all get 
used and exploited, by being harnessed to the capitalist machine for the production of wealth. If we calculate the wealth produced by the capitalist system, but subtract the costs of destruction of natural resources, the balance is hugely negative. Zaman (2014a) provides a more complete discussion, and further references. Minor tweaks cannot fix the system and revolutionary change is required. Jared Diamond (2005) documents how many societies in the past have been destroyed because they failed to make the changes required to adapt to changing circumstances.

Islam offers the foundations for a radical alternative which is desperately needed today. Zaman (2019), explains that the central model of human behavior currently in use in economics textbooks all over the world excludes the heart and soul of human beings from consideration. This leads to dramatic mistakes in understanding human behavior, when decisions are motivated by reciprocity, altruism, gratitude, revenge, indifference, and other emotional and spiritual states. Zaman and Karacuka (2012) give many examples where theories blind economists to the realities of human behavior. It is only after making a radical change in our models of human behavior that it is possible to introduce generosity, cooperation, mutual responsibility, and other social behaviors into our ways of thinking and theorizing, as well as in the institutions which shape our social, economic, and political landscapes. This is an urgent need of the times, since it is precisely selfish greed which is driving humanity towards climacide - destruction of our planetary habitat which will cause the "collapse" of human society.

\section{Are Ethics and Morals Relevant to Economic Science?}

The question itself reflects how strongly our minds have been shaped by the teachings of modern economics. Economics was originally a branch of moral philosophy, and it is self-evident that when we make decisions about what should be produced and who should receive it, ethical judgments are involved. The slogan of Karl Marx, "from each according to his ability, to each according to his need", reflects an ethical judgment about how economic institutions of a society should be shaped. Many authors have studied how economic theories make value judgments without having any awareness of this. For example, the Pareto principle implies that the right to property is sacred, and supersedes the right to life of others. As an illustration of the implications of the Pareto principle, David Gauthier (1986) writes:

The rich man may feast on caviar and champagne, while the poor woman starves at his gate. And she may not even take the crumbs from his table, if that would deprive him of his pleasure in feeding them to his birds. (p. 218)

This is perfectly aligned with the Pareto principle, but completely contrary to Islamic principles. The point here is not to argue about which normative principle is superior, but to show that what economists claim is an objective and scientific principle, conceals within it a strong bias towards the rights of the wealthy to their property, as well as a rejection of the social responsibility of taking care of the weak. Many authors have pointed out how normative principles are hidden within the foundations of statistics. A detailed book length treatment by Hausman and MacPherson (2006), shows how economists routinely make ethical judgments without acknowledging them. Zaman (2012b), shows that making "scarcity" the foundation of economics involves three different normative judgments.

So, to answer the question, economics is not a "science" because human behavior is not subject to laws, unlike physical particles. The freedom of choice that humans enjoy means that all choices are guided by normative considerations regarding good and bad choices. This means that all social sciences must be based on ethical and moral considerations, which provide judgments regarding the choices that we all face, and how we can make them.

The real question here is not whether ethics or morals are relevant to economics. The question is 'how can something so obvious be denied by economists?'. How can we possibly believe that 'free markets provide the best possible results for society', when it is obvious that letting everyone act freely will give massive power to the extremely wealthy. This is obvious from the increasing inequality over the past several decades, as all the gains from growth go to the top $1 \%$. In the rest of this section we focus on answering this variant question: How can economists present their subject as objective and scientific, a positive description of economic realities, when economic theories are full of normative assumptions? 
Since it is impossible to study human behavior without thinking about normative principles which shape his behavior, economic theories are dis-honest, and hide ethical commitments. Many post-modern writers have seen through this deception. An article on the philosophy of Michel Foucault states that "modern human sciences (biological, psychological, social)... purport to offer universal scientific truths about human nature that are, in fact, often mere expressions of ethical and political commitments of a particular society" (Gutting \& Oksala, 2018; Zaman, 2008, p. 14).

The ideological nature of economics has been noted by many top ranked economists. For example, Joseph Stiglitz is reported to have said that "... economics is really a religion. And so why should you be puzzled by the fact that they cling to and never give up their views despite their frequent falsification?" (Bilgrami, 2010, p. 343). Similarly, Frank Hahn said that "Although I never believed it when I was young, ... ideology plays a large role in economics" (Petri \& Hahn, 2003, p. 27). A more detailed examination of economics as a religion is provided at length by Nelson (2014) in his book Economics As Religion: From Samuelson to Chicago and Beyond. This book charts the rise of a 'modern secular religion of economics' that culminates in the twentieth century cultural ideology of the market. In his first volume, Reaching for Heaven on Earth: The Theological Meaning of Economics (1993), Nelson argued that economics became the modern theology that replaced traditional theology as the set of doctrines that give meaning to our social reality and hope to our endeavors for improving our lives (Boettke, Coyne, \& Leeson, 2006, p. 552).

The deceptive role of the assumption of "rationality" is recognized clearly by Hausman and MacPherson (2006), who write that rationality is "a Trojan horse smuggling ethical commitments into the theoretical citadel of positive mainstream economics" (pp. 67-68). In developing the axiomatic basis of modern economic theory, Lionel Robbins said that assumptions about rational behavior were "indisputable facts of experience" (Robbins, 1935, p. 78). The idea that rational behavior requires us to maximize the lifetime pleasure we get out of the consumption of goods and services is in fact exactly what the Holy Qur'ān condemns as the 'worship of desires'.
This becomes clear when we look at the origins of the utilitarian philosophy which lies at the heart of modern economics. Jeremy Bentham invented the philosophy of Utilitarianism as a replacement for religion. Instead of religious standards for morality, he argued that the basis of morality should be pleasure and pain. Any act which yields pleasure is moral and good, while any act which leads to pain is immoral and evil (Crimmins, 2019; Nathanson, n.d.; Bentham, 1789/1879). This is exactly the religion of worship of desire, and has the appearance of sensibility for those who reject God and the afterlife - it seems reasonable to maximize our pleasures during our present lifetime. This is why economic theory centers around "rational" behavior. Rational people do not believe in God and the afterlife, and therefore, they must maximize their pleasures in this life. Obviously, this is a normative principle and is not compatible with Islam.

\section{Is History of Economic Thought Still Relevant?}

One of the most powerful weapons in the arsenal of the top $1 \%$ is the pretense of objectivity. When false theories are passed off as objective facts, then there is no room for context, history, or even reasoned argumentations. Lionel Robbins, the founder of modern economics, states that his assumptions are "indisputable facts of experience" (Robbins, 1935, p. 78). This remains the current methodology of economics, when patent lies about human behavior are passed off as indisputable facts not subject to discussion or debate.

It is only the study of history of ideas which can reveal the twists and turns which have led to the current state of economic theories. It is indisputable that historical experience shapes the theories of the social sciences, which represent ways to understand that experience. Therefore, it is impossible to understand theories without their historical context. For instance, Keynesian macroeconomic theory is a response to the events observed by Keynes in the Great Depression. The following intuitively obvious methodological principle is derived from Zaman (2016b, p. 45):

It is impossible to understand historical experience without a "social science" theoretical framework. It is also impossible to understand theoretical frameworks of "social sciences" without understanding the historical context in which they were developed. 
In light of this principle, it should be clear that history of economic thought, situated within the historical context, is essential. Providing historical context for a theory allows us to intelligently understand and situate the theory, and also, to modify it in accordance with changing historical contexts. This, however, is extremely inconvenient for the rich and powerful, who would like a universal justification for inequality, which has a claim to objectivity, so that it remains valid through changing environments. In order to create such universal justifications, it is often necessary to re-write past history, in order to make it conform to the universal laws it is supposed to follow. This is made evident in George Orwell's Nineteen Eighty-Four (1949), where the central character works in the Ministry of Truth, and is in charge of revising history to conform to official dogma. In the case of economics, Donni Wang (2019) shows how ancient Greek history was distorted by Adam Smith to create justifications for modern capitalism. Also, Hodgson's How Economics Forgot History (2002) contains useful and informative discussion about this issue.

To summarize, the historical context in which ideas are born are of central importance in understanding the import of economic theories. Transitions from household management, to physiocrats, to mercantilism, to classical economics do not represent improvements in the understanding of economic affairs. Rather, each type of economics represents that which was suited to understanding the contemporary era, and the theories evolved to adapt to changing institutional structures governing the economic, political, and social realms. In this evolutionary process, dominant theories were not the ones which provided closest approximation to the truth. Rather, theories emerged as an outcome for the battles for power between different social classes, and were aligned with interests of the rich and powerful segments of society. Even the emergence of Islamic economics in the twentieth century illustrates this principle. As the Islamic world re-gained independence after colonization, they sought to run economic affairs of the Islamic countries using Islamic teachings, rather than importing Western economic systems. In light of this understanding, history of thought is of central importance in understanding economic theories.

\section{Implications for Islamic Economics}

"Reviving the Promise of Islamic Economics" by Zaman (2017) discusses how the first generation of Islamic economists, in the post WW2 era, thought and wrote that Islam offered an economic system that was revolutionary, and radically superior to the dominant systems of capitalism and communism. For reasons related to politics and power, revolutions did not prove feasible, so the second generation made the practical compromise of working with existing capitalist institutional structures, and modifying them to make them Islamic. Thus, emerged the formula that Islamic Economics $=$ Capitalism + Zakat - Interest. That is, the main body of economic thought was to be borrowed from the West, while minor modifications required by Islam would suffice to adapt this system for use in Islamic societies. Many authors who noted this transition have remarked that Islamic economists have renounced their revolutionary intentions and are content to have a small room at the annual meetings of the American Economic Society, as recognition of intellectual content. Even this limited ambition is in dispute as Timur Kuran and other critics have argued that Islamic economic is no more than identity politics and emotional rhetoric, and is devoid of intellectual substance (for documentation and references, see Zaman, 2012a).

In fact, the message of Islam is just as revolutionary today as it was 1440 years ago, when it catapulted ignorant and backwards Arabs to world leadership and launched a civilization which enlightened the world for a thousand years. In all dimensions, Islam offers innovations which are outside the box of possibilities in conventional economics, which cannot imagine the possibility of a society built on cooperation and generosity. Such a society was created by the teachings of Islam, which put mutual love and affection into the hearts of people who had been blood enemies in the past.

While the heterodoxy has offered many good ideas which repair serious defects in conventional economics, none of these alternatives are based on the radical premises of Islam. Both orthodox and heterodox schools of thought agree that the accumulation of wealth is the goal of an economic system, and that social welfare should be measured by worldly prosperity alone. Islam teaches us that the most valuable 
of the creations of Allah is the human being. The goal of development is to realize the potentials for excellence contained within each human being. Realization of these potentials depends on avoiding the distractions created by the pleasures of this world, which are attractive, but deceptive. For a more detailed exposition of the spiritual goals of an Islamic economic system, and the stark contrast with the materialistic goals of Western Economics, see Zaman (2019).

The pioneers of Islamic economics like Maudoodi and Baqir al-Sadr made grand claims for the Islamic economic system. This would provide social justice, ensure that all basic needs were met, and protect all individuals from exploitation. The institutional structures would nurture family, communities, and create bonds of love between the ummah. The responsibility for the welfare of all of humanity, inviting to the good, and prohibiting from evil, was placed on the shoulders of the ummah. All of the resources of the planet are given to us as a trust, and we must nourish, care for, and sustain this trust, passing it on to future generations in a better condition than we received it. Some of the central elements of the message, desperately needed today, can be listed as follows:

\section{References}

Bentham, J. (1879). An Introduction to the Principles of Morals and Legislation. Oxford, UK: Clarendon Press. (Original work published 1789)

Bezemer, D. J. (2009). No one saw this coming: Understanding financial crisis through accounting models (University of Groningen, SOM research school, SOM Research Reports, Vol. 09002). Retrieved from: https://bit.ly/32XeWVp

Bilgrami, A. (2010). Truth, Balance, and Freedom. In J. Franck \& J Bricmont (Eds.), Chomsky Notebook (pp. 334-348). New York, USA: Columbia University Press.

Blanchard, O. (2016). Do DSGE Models Have a Future? (Peterson Institute for International Economics Policy Brief No. PB 16-11). Retrieved from: https://bit.ly/ 2aGR5ln

Boettke, P. J., Coyne, C. J., \& Leeson, P. T. (2006). High Priests and Lowly Philosophers: The Battle for the Soul of Economics. Case Western Reserve Law Review, $56(3), 551-568$
1. Excellence in Conduct. The best Muslim is the one who has the best conduct.

2. Mercy to all Nations. We have the welfare of the entire humankind in our hearts. This is the responsibility entrusted to the Muslim ummah.

3. All men and women are brothers and sisters, born of Adam and Hawwa (Eve). We are all equal, and we are responsible for each other.

4. Power is given to us to help the oppressed, not to oppress.

5. Wealth is given to us so that we can help the needy, not to flaunt it like Qaroon (Korah/ Kurah).

6. The leader of a nation is the servant of the people.

7. All creation is the family of Allah. The way to get near to Allah is to be of service to the creation.

These principles would be the foundations of a radically different system from any currently in existence. The modern world offers a tremendous opportunity and an exciting challenge for the Muslims to translate these revolutionary ideas into a living reality.

Crimmins, J. E. (2019). Jeremy Bentham. In E. N. Zalta (Ed.), The Stanford Encyclopedia of Philosophy (Summer 2019 Edition). Retrieved from: https:// stanford.io/2ZdSTYa

Dehlawi, Shah WaliuAllah. (1995). The Conclusive Argument from God: Shāh Wali Allāh of Delhis Hujjat Allāh al-Bāligha (M. K. Hermansen, Trans.). Leiden, Netherlands: Brill Academic Publishers. (Original work published 1750).

Diamond, J. (2005). Collapse: How societies choose to fail or succeed. New York, USA: Viking Penguin.

Gauthier, D. (1986). Morals by agreement. Oxford, UK: Oxford University Press.

Gauthier, F. (2017, March 5). Robert H. Nelson, "Economics as Religion". Revue du MAUSS permanente. Retrieved from: https://bit.ly/2K9dhTX

Gutting, G., \& Oksala, J. (2018). Michel Foucault. In E. N. Zalta (Ed.), The Stanford Encyclopedia of Philosophy (Spring 2019 Edition). Retrieved from: https://stanford.io/2SMW46Y 
Hausman, D. M., \& McPherson, M. S. (2006). Economic Analysis, Moral Philosophy, and Public Policy (2nd ed.). Cambridge, UK: Cambridge University Press

Hill, Roderic., \& Myatt, Anthony. (2010). The economics anti-textbook: a critical thinker's guide to microeconomics. London, UK: Zed Books.

Hodgson, G. M. (2002). How economics forgot history: The problem of historical specificity in social science. London, UK: Routledge.

Kandehlawi, Muhammad Zakariyya. (1938). Al Aitdal fi Maratib al Rijal [Moderation in the ranking/judging of men]. Lahore, Pakistan: Maktabah Zakariyya.

Keen, S. (2016, August 13). The Slowly Changing Resistance of Economists to Change. Forbes Magazine. Retrieved from: https://bit.ly/2SLHCvS

Lucas, R. E. (2004, May 1) The Industrial Revolution: Past and Future. The Region, Federal Reserve Bank of Minneapolis. Retrieved from: https://bit.ly/1VHuOlY

Madi, M. A., \& Reardon, J. (Eds.). (2014). The Economics Curriculum: Towards a radical reformulation. Bristol, UK: WEA Books.

Marx, K., \& Engels, F. (1908). The Communist Manifesto. New York, USA: New York Labor News. (Original work published 1848)

Menocal, M. R. (2002). The Ornament of the World: How Muslims, Jews, and Christians Created a Culture of Tolerance in Medieval Spain. Boston, USA: Little, Brown and Company.

Morgan, J. (2015). Is economics responding to critique? What do the UK 2015 QAA subject benchmarks indicate? Review of Political Economy, 27(4), 518-538.

Nathanson, S. (n.d.). Act and Rule Utilitarianism. The Internet Encyclopedia of Philosophy. Retrieved from: https://www.iep.utm.edu/util-a-r/

Nelson, R. H. (1993). Reaching for Heaven on Earth: The Theological Meaning of Economics. Lanham, Maryland, USA: Rowman \& Littlefield.

Nelson, R. H. (2014). Economics as religion: From Samuelson to Chicago and beyond. Pennsylvania, USA: Penn State University Press.

Orwell, G. (1949). Nineteen Eighty-Four. London, UK: Secker \& Warburg.

Petri, F., \& Hahn, F. (2003). General Equilibrium: Problems and Prospects. London, UK: Routledge.

Reardon, J. (2019). Dialogue on Reform in Mainstream Economics and its Implications for the Islamic Economics Discipline. Journal of King Abdulaziz University: Islamic Economics, 32(2), 61-75.

Robbins, L. (1935). An essay on the nature and significance of economic science (2nd ed.). London, UK: Macmillan.
Romer, P. (2016). The Trouble With Macroeconomics (Working Paper). Retrieved from: https://bit.ly/ 2LatJpW

Walbridge, J. (2002). The Islamic Art of Asking Questions: 'Ilm al-Ikhtiläf and the Institutionalization of Disagreement. Islamic Studies, 41(1), 69-86.

Wang, D. (2019, February 7). No Go from the Get Go: Adam Smith's Bad History, Lessons from Ancient Greece, and the Need to Subsume Economics. The Economic Historian. Retrieved from: https://bit.ly/2GzXcFP

Zaman, Asad. (2008). Islamic Economics: A Survey of the Literature (University of Birmingham: Religions and Development Research Programme Working Paper No. 22). Retrieved from: https://bit.ly/2GwMyQg

Zaman, Asad. (2010). The Rise and Fall of the Market Economy. Review of Islamic Economics, 14(2), 123-155.

Zaman, Asad., \& Karacuka, Mehmet. (2012). The Empirical Evidence Against Neoclassical Utility Theory: A Review of the Literature. International Journal of Pluralism and Economics Education, 3(4), 366-414.

Zaman, Asad. (2012a) Crisis in Islamic Economics: Diagnosis and Prescriptions. Journal of King Abdulaziz University: Islamic Economics, 25(1), 147-169.

Zaman, Asad. (2012b). The Normative Foundations of Scarcity. Real-World Economics Review, 61, 22-39.

Zaman, Asad. (2014a). Evaluating the Costs of Growth. Real-World Economics Review, 67, 41-51.

Zaman, Asad. (2014b). Challenging the Current Economics Curriculum: Creating Challengers and Changes. In M. A. Madi \& J. Reardon (Eds.), The Economics Curriculum: Towards a Radical Reformulation. Bristol, UK: WEA Books.

Zaman, Asad. (2016a). Positivist misconceptions: an obstacle to understanding pluralism. International Journal of Pluralism and Economics Education, 7(1), 93-96.

Zaman, Asad. (2016b). The Methodology of Polanyi's Great Transformation. Economic Thought, 5(1), pp. 44-63.

Zaman, Asad. (2017). Reviving the Promise of Islamic Economics. International Journal of Economics, Management and Accounting, 25(2), 205-225.

Zaman, Asad. (2018, July 26). Quotes Critical of Economics [Blog post]. WEA Pedagogy Blog. Retrieved from: http://bit.do/azquo

Zaman, Asad. (2019). Islam's Gift: An Economy of Spiritual Development. The American Journal of Economics and Sociology, 78(2), 443-491. 
Asad Zaman [BS Math MIT (1974), MS Stats (1976) and Ph.D. Econ (1978) Stanford] has taught economics and econometrics at leading universities like Columbia, U. Penn., Johns Hopkins, Cal. Tech. and Bilkent University, Ankara. He has held many top academic and administrative positions throughout his career. Most recently, he was the Vice Chancellor of the Pakistan Institute of Development Economics. Formerly, he held the position of Director General of the International Institute of Islamic Economics, International Islamic University, Islamabad. His textbook Statistical Foundations of Econometric Techniques (Academic Press, NY, 1996) is widely used as a reference in advanced graduate courses. He is the managing editor of International Econometric Review and Pakistan Development Review. His research on Islamic economics is widely cited, and has been highly influential in shaping the field. His publications in top ranked journals like Annals of Statistics, Journal of Econometrics, Econometric Theory, Journal of Labor Economics, etc. have more than 1300 citations as per Google Scholar.

E-mail: asaduzaman@gmail.com ; asad.zaman@alumni.stanford.edu 


\title{
إطلاق ثورة في الاقتصساد، تقوم على القيم الإسلامية
}

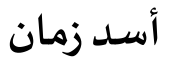 \\ نائب الممدير السابق، معهد باكستان لاقتصاديات التنمية، إسلام أباد
}

المستخلص. يعاني الاقتصاد التقليدي من عيوٍٍ جوهريةٍ عميقة يتعذر في ضوئها إصلاحها وتصحيحها.

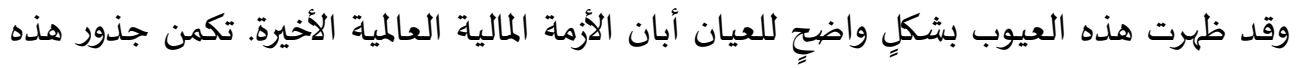

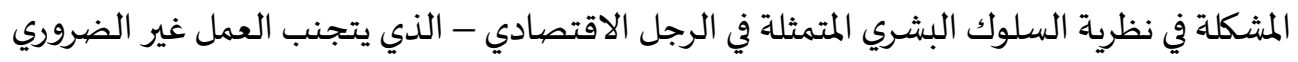

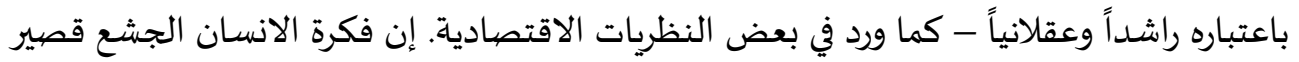

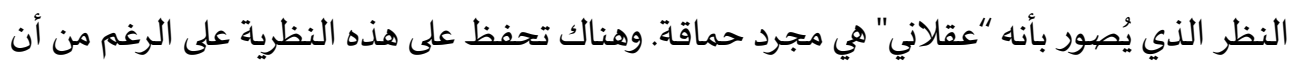

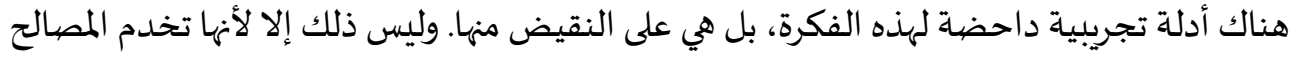
الأيديولوجية للطبقات الرأسمالية الغنية والقوية. لقد أدت فلسفة تعظيم الثروة إلى تدمير العائلات

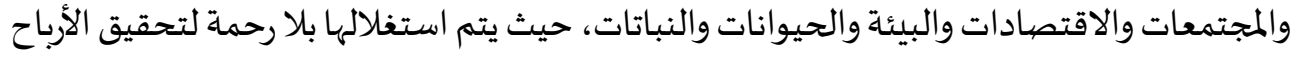

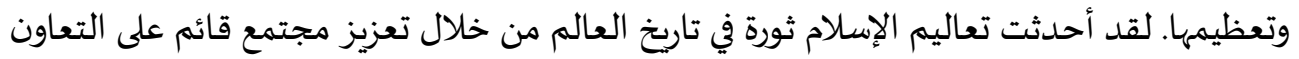

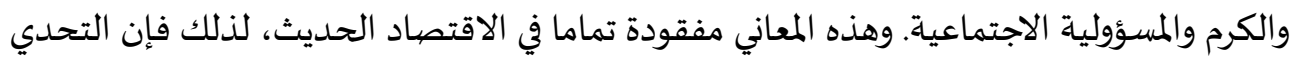
الذي يواجه المسلمين اليوم هو إظهار هذه القيم من خلال ترجمة هذه الأفكار إلى واقع ملموس. الكلمات الدَّالة: تعليم الاقتصاد، التعددية، الاقتصاد الإسلامي، القوة/المعرفة.

A2, B2, Y8 : JEL تصنيف تصنيف G0, G1, H1, H22, H6 : KAUJIE 